\title{
Cypermethrin Influence on Oxidative Status and Anxious Behaviour in Paracheirodon innensi Species
}

\author{
GABRIELA DUMITRU', ELENA TODIRASCU CIORNEA ${ }^{1 *}$, ION SANDU2,3, LUCIAN HRITCU ${ }^{1}$ \\ ${ }^{1}$ Alexandru Ioan Cuza University of lasi, Faculty of Biology, Department of Biology, 11 Carol I Blvd., 700506, lasi, Romania \\ ${ }^{2}$ Alexandru loan Cuza University of lasi, Faculty of Geography and Geology, 22 Carol I Blvd., 700506, Iasi, Romania \\ ${ }^{3}$ Romanian Inventors Forum, 3 Sf. Petru Movila St., BI. L11, III/3, 700089, Iasi, Romania
}

\begin{abstract}
The non-discriminatory use of pesticides and herbicides to increase agricultural production has caused great concern, as these products are likely to reach the aquatic environment, thus representing a health problem for aquatic species, but also for humans. Cypermethrin, a pyrethroid type II insecticide, is widely used in agriculture, but also for pest control of plants and stored agricultural products, as well as for combating the biological vectors of human and animal diseases. The administration of cypermethrin to Paracheirodon innensi determined ample variations in the activity of oxidative stress enzymes and malondialdehyde concentration, in close correlation with the concentration used, but also the occurrence of some locomotor deficiency and an anxiety state.
\end{abstract}

Keywords: neon tetra, cypermethrin, anxiety, locomotion, oxidative stress

In last years, there has been a widespread use of pyrethroids in the field of agriculture to combat insects (malaria, dengue etc.) [1, 2] the ecotoxicological impact of pyrethroids in the pest control being incompletely elucidated [3]. The effects of long-term pesticide administration are reflected in environmental pollution, but also in the increasing occurrence of severe acute and chronic human poisoning [4-6].

The synthetic pyrethroids, such as cypermethrin, fenvalerate and deltamethrin, are extensively used in the control of mosquitoes and in the treatment of ectoparasitic diseases, in the recent decades beginning used in garden humans for the control of parasitic insects.

Studies on various fish species have highlighted the negative effects of these insecticides that cause alterations in the haematological profile of the species Channa punctatus and Prochilodus lineatus $[7,8]$ as well as on the reproduction physiology of Cyprinus carpio and Atlantic salmon [9, 10]. Also, Kumar etal., [11, 12] reported significant morphological, behavioral, biochemical, neurotoxic effects as well as induction of oxidative stress in Channa punctatus and Clarias batrachus due to cypermethrin administration.

Also, other authors $[13,14]$ signal, both the invertebrates and the vertebrates, the drastic effects of cypermethrin pyrethroid of the hydrophobic insecticide class, used chemoterapeutically in salmon farms for the control of copepodic parasite infestations [15].

The literature data $[3,16,17]$ show that cypermethrin a type II pyrethroid insecticide has a large spectrum of use, particularly in the control of insects from the Coleoptera and Lepidoptera genus from the cultures of citrus, cotton, vegetables, as well as in the eradication of cockroaches, fleas and termites etc.

The cypermethrin - acyano-3-phenoxybenzyl ester of 2,2-dimethyl-3-(2,2-dichlorovinyl)-2-2-dimethyl cyclopropane carboxylate is highly toxic to fish and aquatic invertebrates because it is metabolized and eliminated significantly more slowly by fish than by mammals or birds [18].

The goal of this study was to highlight the effects of cypermethrin in doses of $0.04,0.08$ and $0.15 \mu \mathrm{g} / \mathrm{L}$ respectively, on the anxiogenic profile and the oxidative status of neon tetra.

\section{Experimental part \\ Biological material}

We taken into study Paracheirodon innensi specimens, fed with Norvitall - a supplement containing cereal and fish meal, vegetable protein, crustaceans and shrimps, plankton and spirulina, as well as a number of vitamins, vegetable oils and aromatic herbs. The fish were kept in aquariums for 7 days to accommodate laboratory conditions and were subsequently divided into 4 experimental variants - one control group and the other three at which was administered cypermethrin in concentrations of $0.04,0.08$ and respectively, $0.15 \mu \mathrm{g} / \mathrm{L}$ water, the treatment being in a single dose. After testing the anxiogenic profile, the fish were used to determine the activity of the oxidative stress enzymes, respectively the malondialdehyde concentration.

\section{Antioxidant state determination}

The superoxide-dismutase (SOD) activity was determined by the Nitro-Blue-Tetrazolium method, catalase (CAT) by the Sinha spectrophotometric method, glutathione peroxidase (GPX) by the 5,5'-dithiobis-2-nitrobenzoic acid method and of the malondialdehyde concentration (MDA) by the 2-thiobarbituric acid method [19-22].

\section{Behavioral tasks}

In our studies, a Philips Webcam SPC900NC camera recorded zebrafish behaviors and the videos analyzed using ANY-maze ${ }^{\circledR}$ so ftware (Stoelting CO, USA).

\section{Novel tank diving test (NTT, anxiety test)}

The position (bottom $x$ upper levels) was considered an index of anxiety, similar to the position near the wall versus the center of an open field with rodents [23]. Fish were transferred individually to a test aquarium $(24 \times 8 \times 20 \mathrm{~cm}$; width $\times$ depth $\times$ height) and filmed for $6 \mathrm{~min}$. The following parameters were analyzed: (i) total distance traveled (m); (ii) entries in the upper zone of the tank; and (iii) time in the upper zone of the tank (s). 


\section{Results and discussions}

The oxidative stress, a phenomenon that occurs as a result of an imbalance in the oxidant/antioxidant balance and manifests itself through the inability to defend the antioxidant component, has attracted more attention in recent years, many researches focusing on deciphering the mechanisms that stand at the basis of this process [24-26].

Literature data [27-28] points out that maintaining the balance between the pro- and antioxidant processes at optimal rates is particularly important for ensuring cellular functioning, disruptions of this balance, in the sense of increasing the pro- oxidation component, leading to the occurrence of oxidative alterations [29].

Animal organisms possess a true arsenal of protection against oxidative stress, which, in the normal way is very efficacy $[30,31]$. It has been shown that in aquatic organisms, oxidative stress can be induced by various compounds and rapidly generates reactive oxygen species (ROS) such as superoxide and hydroxyl radical, nitric oxide, hydrogen peroxide and singlet oxygen species, ozone or aldehydes reactive [32]. In addition, ROS can oxidize proteins, lipids and nucleic acids, often leading to real disasters at different cellular compartments or even cell death $[33,34]$.

Pesticides are chemicals that can cause various secondary effects, such as the generation of reactive oxygen species [35] and inhibition of specific enzymes [36], with direct influence on the antioxidant defense system, also acting as inductors of the heat shock protein in tissues and cells [37].

Many authors [38-42] demonstrated that, once arrived in the body, pesticides can induce oxidative stress, leading to the generation of free radicals and at the same time causing lipid peroxidation. In addition, the accumulation and persistence of various chemical agents such as pesticides and insecticides constitute a real threat to aquatic life, due to the acute or chronic poisoning phenomenon of them [43-45].

The antioxidant defensive begins with the action of SOD, the oxidoreductase involved in the conversion of superoxide radicals $\left(\mathrm{O}^{\circ}{ }^{-}\right)$, the significant increase of its activity in our samples, suggesting the role of this hemoprotein in the cell detoxification process. Thus, if in the control group the superoxide-dismutase activity reached an average value of $0.216 \pm 0.031 \mathrm{USOD} / \mathrm{mg}$ protein (fig. 1), with the increase of the pesticide concentration to 0.04 and $0.15 \mu \mathrm{g} / \mathrm{L}$ respectively, it was found an increasing of radicals $\mathrm{O}_{2}$.mobilizing rate $(0.349 \pm 0.031 \mathrm{USOD} / \mathrm{mg}$ protein, respectively $0.346 \pm 0.031 \mathrm{USOD} / \mathrm{mg}$ protein), placing w ell above the reference value. In addition, in the batch treated with cypermethrin in the concentration of $0.08 \mu \mathrm{g} / \mathrm{L}$, the enzymatic activity is triplet $(0.624 \pm 0.024 \mathrm{USOD} / \mathrm{mg}$ protein) than that one recorded in the reference variant.

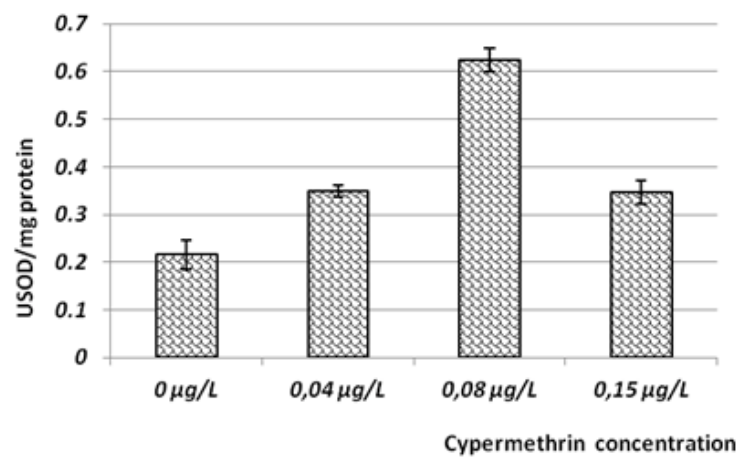

Fig. 1. SOD activity in Paracheirodon innensi
In fact, literature from the field shows that, in fish, cypermethrin - compound with higher toxicity in these aquatic organisms is metabolized and eliminated with a significantly lower rate compared to mammals and birds [18].

The analysis of experimental results on CAT activity, the enzyme meeting from the simplest to the most complex organisms, which plays a role in cellular protection against the harmful effects of hydrogen peroxide [46-48] highlights the influence of this neurotoxic synthetic pyrethroid on Paracheirodon innensi, with a wide range of values among the experimental groups (fig. 2). Thus, the maximum activity level could be highlighted in the reference samples (103.159 \pm 5.329 UCAT/mg protein), while in the treated samples CAT activity decreases as the increase in cypermethrin concentration $(84.326 \pm 6.159 \mathrm{UCAT} / \mathrm{mg}$ protein at concentration of $0.04 \mu \mathrm{g} / \mathrm{L}, 53.489 \pm 3.0648 \mathrm{UCAT} /$ $\mathrm{mg}$ protein, at $0.08 \mu \mathrm{g} / \mathrm{L}$ and, respectively $36.157 \pm 4.228$ UCAT/mg protein at $0.15 \mu \mathrm{g} / \mathrm{L}$ ).

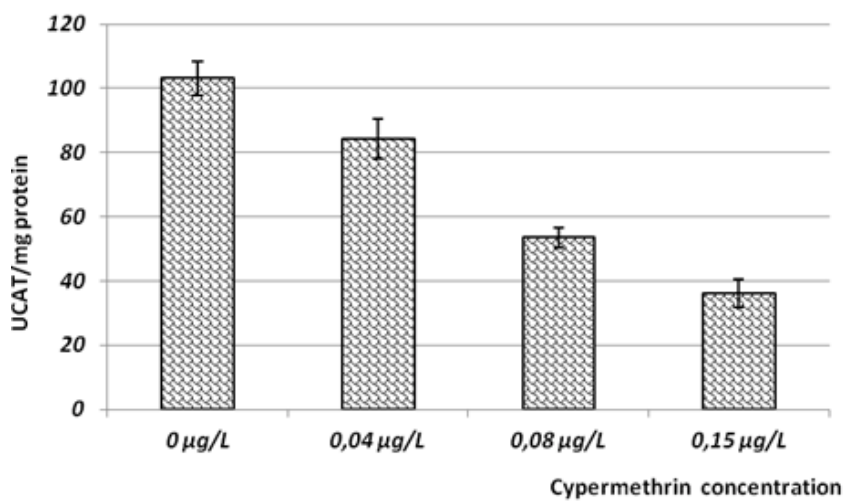

Fig. 2. CAT activity in Paracheirodon innensi

Besides, other authors [49] show that catalasic activity is decisively influenced, on the one hand, by the time when aquatic organisms come in direct contact with the chemical agent, and on the other hand by temperature and the degree of salinity of the water.

The literature data [25] indicates a direct correlation between the decrease of CAT activity and the physiological status of the organisms affected by pyrethroids, in the sense that with the decrease of the average value thresholds of CAT there is an alteration of the physiological condition of the body which, often, leads to the death of the animal if vital tissues and organs are affected.

The reactive oxygen species (e.g., hydrogen peroxide and the superoxide radical, the latter being able to combine rapidly with nitric oxide to form the peroxynitrite or, spontaneously, enzymatically, respectively, can be dismantled in $\mathrm{H}_{2} \mathrm{O}_{2}$ and $\mathrm{O}_{2}$ ) are produced by all cells during normal oxidative respiration and, when left unchecked by antioxidant systems, can cause oxidative disasters in the levels of proteins, membrane lipids and DNA $[50,51]$.

In this regard, another enzyme taken in the study is GPX, an intracellular antioxidant enzyme that has the role of catalysing the reduction of hydrogen peroxide in water and lipid hydroperoxides to the corresponding alcohols to limit its harmful effects being present in blood plasma, erythrocytes and various animal tissues [51, 52].

As can be seen from figure 3, GPX records an average activity of $0.075 \pm 0.004 \mathrm{UGPX} / \mathrm{mg}$ protein in the reference experimental varaiant, so that in the case of administration a pesticide concentration of $0.04 \mu \mathrm{g} / \mathrm{L}$ to observe a higher level of oxidative stress, the mobilization rate of the free radicals from GPX being higher compared to the control group $(0.094 \pm 0.002 \mathrm{UGPX} / \mathrm{mg}$ protein). In contrast, for the batch treated with a concentration of $0.08 \mu \mathrm{g} / \mathrm{L}$, the enzyme 


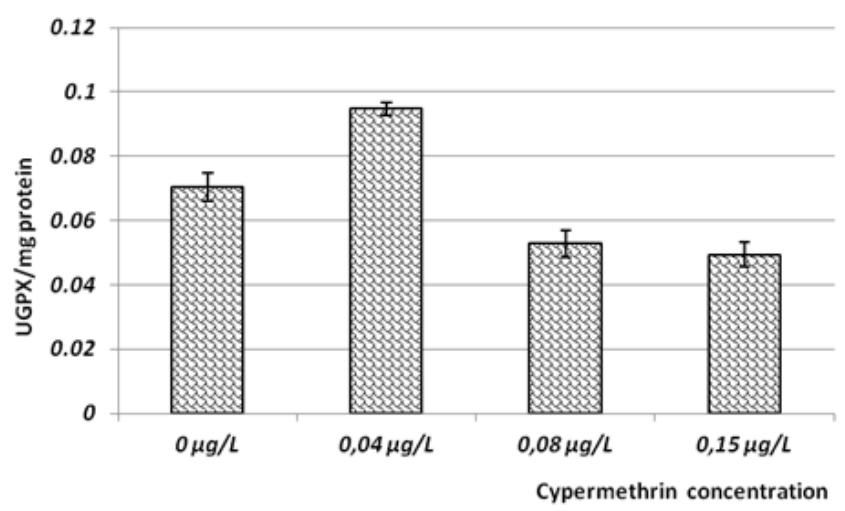

Fig. 3. GPX activity in Paracheirodon innensi

displays a value below the reference threshold $(0.052 \pm 0.004 \mathrm{UGPX} / \mathrm{mg}$ protein), while at the maximum concentration of cypermethrin administered there is a decrease of the enzymatic activity $(0.0493 \pm 0.003$ UGPX/ mg protein) with $70.35 \%$ compared to the control group.

As can be seen from graphical representations, CAT and GPX (enzymes that reduce peroxide levels and thus protect cells from peroxide disasters) responded somewhat differently to cypermethrin treatment, the literature data also indicating that GPX acts in tandem with CAT to remove excess hydrogen peroxide, having, perhaps, an even greater contribution to counteracting the toxicity of this free radical [53]. Moreover, compared to CAT, GPX has a much higher affinity for the hydrogen peroxide molecule which it can detoxify even when it is found in very low concentrations $[26,54]$

Intensification of lipid peroxidation and accumulation of free radicals may affect the activity of protective enzymes but also of non-enzymatic antioxidants that are sensitive indicators of the increase in oxidative stress level [42], with an important role in the etiopathogenesis of several neuropsychiatric disorders such as Parkinson's disease, Alzheimer's disease, schizophrenia, anxiety or bipolar disorder etc., oxidative stress affecting nervous function through extremely dynamic processes that are not always related to the slow aging process [55].

The free radicals, highly unstable compounds, quickly engage in redox-like biochemical reactions with various cellular structures, resulting in structural and functional changes of these, following these reactions occurring irreversible cellular alterations. From peroxidation of unsaturated fatty acids results reactive aldehydes which act further on other structures, producing new cellular lesions [56], such an example of reactive aldehyde being the MDA - marker of oxidative stress and oxidative status of the animal and human organism [57].

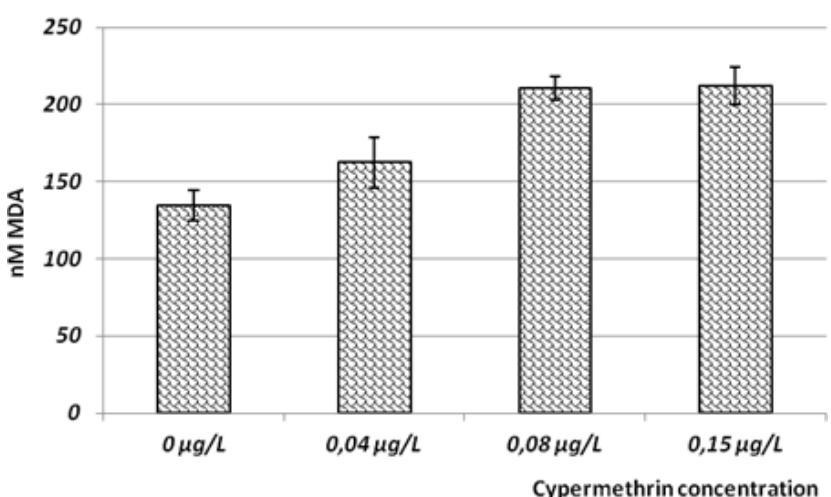

Fig. 4. MDA concentration in Paracheirodon innensi

The MDA concentration in Paracherodins innensi batches exposed to cypermethrin treatment (fig. 4) shows an increasing trend from the reference group to the maximum concentration of cypermethrin administered. Thus, if MDA reaches the mean value threshold of $134.659 \pm 9.981 \mathrm{nM}$, at the concentration of $0.04 \mu \mathrm{g} / \mathrm{L}$ there is a jump of MDA concentration (162.469 $\pm 16.159 \mathrm{nM})$, that at the highest level of pesticide on liter of water, to achieve an average content of $210.56 \pm 7.596 \mathrm{nM}$ (at 0.08 $\mu \mathrm{g} / \mathrm{L}$ ) and $212.357 \pm 12.248 \mathrm{nM}($ at $0.15 \mu \mathrm{g} / \mathrm{L}$ ), respectively.

Our findings are supported by the results of other authors [3] showing the marked increase in lipid peroxidation in various animal tissues as a direct result of the application of cypermethrin in a manner dependent on the administered concentration.

Taking into account that behavioral manifestations are sensitive indicators of the toxic effect due to the presence of different pyrethroids present in the living environment, another objective of our study was to evaluate the anxiogenic profile and, implicitly the locomotor function in the analyzed batches.

Because the administration of cypermethrin in dose of $0.15 \mu \mathrm{g} / \mathrm{L}$ determined death of the whole experimental lot, the death of the fish occurring at $2 \mathrm{~h}$ after application, tests on behavioral parameters were performed only in the control group and variants treated with the minimum doses of cypermethrin $(0.04$ and $0.08 \mu \mathrm{g} / \mathrm{L})$.

As shown in figure $5 B$, cypermethrin significantly decrease the mobility (distance; $p<0.0001$; fig. 5B) and consequently reduction in the number of entries $(p<0.001$ for $0.04 \mu \mathrm{g} / \mathrm{L}$ and $p<0.0001$ for $0.08 \mu \mathrm{g} / \mathrm{L}$; fig. $5 \mathrm{~B}$ ) and in the time spent in the upper zone of the tank $(p<0.001$; fig. $5 D)$. In the figure 5A, NTT tracking locomotor pattern of the control group was demonstrated by normal swimming all over the tank while this pattern was attenuated by cypermethrin administration in a dose-dependent manner.
A

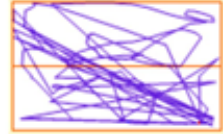

Control

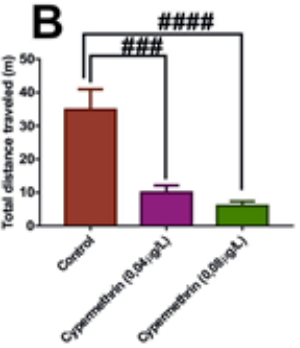

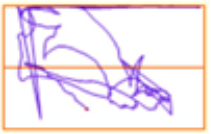

Cypermethrin
(0.04 ug/L)

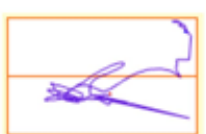

Cypermethrin
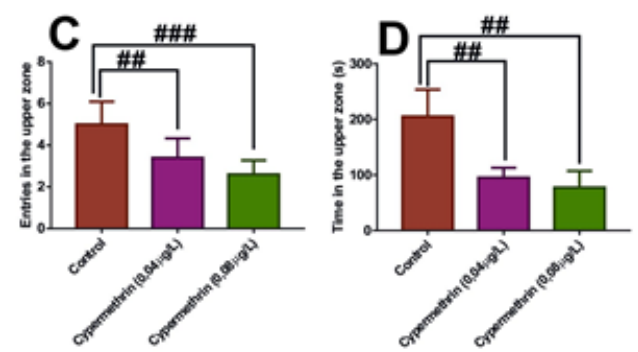

Fig. 5. Effects of cypermethrin $(0.04$ and $0.08 \mu \mathrm{g} / \mathrm{L})$ on the behavioral parameters ( $B$ - total distance traveled $(m), C$ entries in the upper zone and $D$ - time in the upper zone (s)) in zebrafish submitted to a novel tank test. Data are expressed as mean \pm S.E.M. (one-way ANOVA, $n=6$ ). A Representative locomotion tracking patterns of control, cypermethrin $(0.04 \mu \mathrm{g} / \mathrm{L})$ and cypermethrin $(0.04 \mu \mathrm{g} / \mathrm{L})$. For

Turkey's post hoc test: \#\#\#p < 0.0001: control vs.

cypermethrin $(0.04$ and $0.08 \mu \mathrm{g} / \mathrm{L})$ and \#\#p $<0.001$ : control vs. cypermethrin ( 0.04 and $0.08 \mu \mathrm{g} / \mathrm{L})$ 
Our results clearly demonstrated that fish exposed to cypermethrin remain less in the upper zone of the tank, demonstration anxiogenic profile. How ever, this effect could be attributed to hypo-locomotion as evaluated by decrease of the total distance traveled and the number of entries in the upper zone of the tank. Hypo-locomotion is considered as an important indicator of anxiety-like behavior [58]. The observed effects could be also attributed to neurotoxic effects of cypermethrin. Furthermore, our data are in line with previous reports, demonstrated that cypermethrin induced behavioral anomalies in Labeo rohita and in adult zebrafish $[59,60]$.

The surfacing phenomenon of Paracheirodon innesni observed under cypermethrin exposure might be due to hypoxic condition of the fish, also reported by Radhaiah and Jayantha, 1988 [61] in Tilapia mosaambica species exposed to fenvarelate. The increased surfacing during the initial periods of exposure to cypermethrin concentrations suggests an elevated rate of metabolism. Changes in ventilation rate and surfacing frequencies are the general symptoms noticed in the fish after exposure to the pesticide and these activities help the fish to avoid contact with poison and fight against stress [62].

Besides, in trout was also observed the migration of the fish to the bottom of the tank following the addition of cypermethrin, indicating the avoidance behaviour of the fish [63].

In Anabas testudinius [64] the opercular movement of the fish ceases immediately following exposure to cypermethrin. The decrease in opercular movement and corresponding increase in frequency of surfacing of fish indicates that fish adaptively shifts towards aerial respiration (by obtaining atmospheric oxygen), the fish trying to avoid contact with the pesticide through gill chamber [59].

\section{Conclusions}

The experimental results obtained allowed us to formulate the following general conclusions:

Cypermethrin administration has decisively influenced the activity of oxidative stress enzymes, there being significant differences between the reference group and the experimental variants, our data indicating a positive correlation between the genotoxicity of cypermethrin and the level of free radicals.

The enzymatic activity and MDA concentration, respectively, varied according to the dose of cypermethrin administered in the experimental variant treated with 0.15 $i g / L$, the pesticide producing lethality of the entire batch.

The behavioral tests have shown that cypermethrin induces anxiety and causes significant loss of motor coordination.

\section{References}

1.ANSARI, M.A., RAZDAN, R.K., J.Am.Mosq.Control. Assoc., 17, 2001, p. 131.

2. KROEGER, A., LENHART, A., OCHOA, M., VILLEGAS, E., LEVY, M., ALEXANDER, N., MCCALL, P.J., Br. Med. J., 332, 2006, p. 1247.

3. ANSARI, R., RAHMAN, S., KAUR, M., ANJUM, S., RAISUDDIN, S., Ecotoxicology and Environmental Safety, 74, 2011, p. 150-156.

4. YAMASHITA, M., TANAKA, J., ANDO, Y., Vet. Hum. Toxicol., 39, 1997, p. 84.

5. PRAKASAM, A., SETHUPATHY, S., LALITHA, S., Int. J. Clin. Chem., 310, 2001, p. 107.

6. BRADBERRY, S.M., CAGE, S.A., PROUDFOOT, A.T., VALE, J .A., Toxicol. Rev., 24, 2005, p. 93.

7.SAXENA, K.K., SETH, N., Bull. Environ. Contam.Toxicol., 69, 2002, p. 364.
8. PARMA, M.J., LOTESTE, M., CAMPANA, M., BACCHETTA, C., J. Environ. Biol., 28, 2007, p. 147.

9. KOPRUCU, K., AYDIN, R., Pestic. Biochem. Physiol., 80, 2004, p. 47. 10. AYDIN, R., KOPRUCU, K., DORUCU, M., KOPRUCU, S.S., PALA, M., Aquacult. Int., 13, 2005, p. 451.

11. KUMAR, A., SHARMA, B., PANDEY, R.S., Chemosphere, 83, no. 4, 2011, p. 492.

12. KUMAR, A., SHARMA, B., PANDEY, R.S., Cell. Mol. Biol., 58, 2012, p. 153.

13. GOWLAN, B.T., MOFFAT, C.F., STAGG, R.M., HOULIHAN, D.F., DAVIES, I.M., Mar. Environ. Res., 54, 2002, p. 169.

14. DAS, B.K., MUKHERJEE, S.C., Comp. Biochem. Physiol. C., 134, 2003, p. 109.

15. HART, J., THACKER, J ., BRAIDWOOD, J ., FRASER, N., MATTHEWS, J., Vet. Rec., 140, 1997, p. 179.

16. SHASHIKUMAR, S., RAJINI, P.S., Pestic. Biochem. Physiol., 97, 2010, p. 235.

17. TAJU, G., ABDUL MAJEED, S., NAMBI, K.S.N., FAROOK, M.A., VIMAL, S., SAHUL HAMEED, A.S., Pesticide Biochemistry and Physiology, 113, 2014, p.15.

18. BRADBURY, S.P., COATS, J.R., Environ. Toxicol. Chem., 8, 1989, p. 373.

19. DOBRIAN, A.D., DAVIES M.J., SCHRIVER S.D., LAUTERIO T.J., PREWITT R.L., Hypertension, 37, 2001, p. 554.

20. COJ OCARU, D.C., Enzimologie practicã. Ed. Tehnopress, lasi, 2005.

21. PINTILIE, O., ION, L., SURLEVA, A., ZAHARIA, M., TODIRASCU CIORNEA, E., CIUBOTARIU, E., BALAN, A., DROCHIOIU, G., SANDU, I., Rev. Chim. (Bucharest), 67, no. 4, 2016, p. 687.

22. TODIRASCU-CIORNEA, E., DUMITRU, G., SANDU, I., Rev. Chim. (Bucharest), 69, no. 8, 2018, p. 2160.

23. BENCAN, Z., SLEDGE, D., LEVIN, E. D., Pharmacology Biochemistry and Behavior, 94, 2009, p. 75.

24. TUZMEN, N., CANDAN, N., KAYA, E., DEMIRYAS, N., Cell Biochem. Funct., 26, 2008, p. 119.

25. SHARMA, K.D., ANSARI, A.B., Research Journal of Environmental Toxicology, 7, no. 1, 2013, p. 38.

26. LEFTER, R.M., Studiul modificarilor unor parametri biochimici in stresul oxidativ pe modele animale de boli neuropsihiatrice. PhD Thesis, Universitatea Alexandru Ioan Cuza Iai, 2014.

27. VERRI, M., PASTORIS, O., DOSSENA, M., AQUILANI, R., GUERRIERO, F., CUZZONI, G., VENTURINI, L., RICEVUTI, G., BONGIORNO, A.I., International J ournal of Immunopathology and pharmacology, 25, no. 2, 2012, p. 345.

28. VINAGRE, C., MADEIRA, D., NARCISO, L., CABRAL, N.H., DINIZ, M., Ecological Indicators, 23, 2012, p. 274.

29.RAHAL, A., KUMAR, A., SINGH, V., YADAV, B., TIWARI, R., CHAKRABORTY, S., DHAMA, K., BioMed Research International, Article ID 761264, 2014, http://dx.doi.org/10.1155/2014/761264

30.STOREY, K.B., Braz. J. Med. Biol. Res., 29, 1996, p. 1715.

31.KLEIN, D.R., DIAS BORGES, V., ROSA, C.E., COLARES, E.P. ROBALDO, R.B., MARTINEZ, P.E., BIANCHINI, A., J ournal of Thermal Biology, 68, 2017, p. 110.

32.NONGMAITHEM, R., LODHI, M.S., SAMAL, P.K., DHYANI, P.P., SHARMA, S., International J ournal of Conservation Science, 7, no. 2, 2016, p. 523.

33.LUSHCHAK, V.I., Aquatic Toxicol., 101, 2011, p. 13.

34.BIRBEN, E., SAHINER, U.M., SACKESEN, C., ERZURUM, S., KALAYCI, O., World Allergy Organ J., 5, no. 1, 2012, p. 9.

35.D'SOUZA, U.J.A., Borneo Journal of Medical Sciences, 11, no. 1, 2017, p. 9.

36.EKINCI, D., BEYDEMIR, S., Pesticide Biochem. Physiol., 97, 2010, p. 66.

37.MAHMOOD, K., JADOON, S., MAHMOOD, Q., IRSHAD, M., HUSSAIN, J., BioMed Research International, Article ID 564136, 2014, http:// dx.doi.org/10.1155/2014/564136

38.AGRAWAL, D., SULTANA, P., GUPTA, G.S.D., Food Chem. Toxicol., 29, 1991, p. 459.

39.KHRER, J.P., Crit. Rev. Toxicol., 23, 1993, p. 21. 
40.ALMEIDA, M.G., FANINI, F., DAVINO, S.C., AZNAR, A.E., KOCH, O.R., BARROS, S.B.M., Hum. Exp. Toxicol., 16, 1997, p. 257.

41.KOPRUCU, S.S., YONAR, E., SEKER, E., Bull. Environ. Contam. Toxicol., 81, 2008, p. 253.

42.YONAR, M.E., SAKIN, F., Pesticide Biochemistry and Physiology, 99, 2011, p. 226.

43.LANGSTON, W.J., Heavy Metals in the Marine Environment. Boca Raton, Florida: CRC Press, 1990.

44.KOPRUCU, S.S., KOPRUCU, K., URAL, M.S., Bull Environ Contam Toxicol, 76, 2006, p. 59.

45.AMIN, K.A., HASHEM, K.S., Veterinary Research, 8, 2012, p. 45. 46.THANNICKAL, V.J ., FANBURG, B.L., American J ournal of PhysiologyLung Cellular and Molecular Physiology, 279, 2000, p.1005.

47.ODAJIMA, N., BETSUYAKU, T., NAGAI, K., MORIYAMA, C., WANG, D., TAKIGAWA, T., OGINO, K., NISHIMURA, M., Respiratory Research, 11, 2010, p. 183.

48.De MAGALHAES, C.S., TAKARADA, J.E., COSTA CARVALHO, N., CARVALHO, D.C., DE ANDRADE, F.L., BATISTA FERREIRA, E., LUCCAS, P.O., AZEVEDO, L., Journal of Chemistry, Article ID 8570321, 2016, http://dx.doi.org/10.1155/2016/8570321

49.TU, H.T., SILVESTRE, F., DE MEULDER, B., THOME, J.P., PHUONG, N.T., KESTEMONT, P., Chemosphere, 86, 2012, p. 83.

50.LIOCHEV, S.I., FRIDOVICH, I., Free Radic Biol Med., 42, no. 10, 2007, p. 1465.

51.LUBOS, E., LOSCALZO, J., HANDY, D.E., Antioxid. Redox Signal., 15, no. 7, 2011, p. 1957.

52.DUMITRU, G., DIRVARIU, L., BARBACARIU, C.A., MIRON, I., SANDU, I., TODIRASCU-CIORNEA, E., Rev. Chim. (Bucharest), 69, no. 11, p. 4046.
53.DINU, D., MARINESCU, D., MUNTEANU, M.C., STAICU, A.C., COSTACHE, M., DINISCHIOTU, A., Arch. Environ. Contam. Toxicol., 58, 2010, p. 757.

54.DUMITRU, G., TODIRASCU-CIORNEA, E., HRITCU, L., SANDU, I.G., Rev. Chim. (Bucharest), 69, no. 5, 2018, p. 1194.

55.SMITH, M.P, CASS, W.A., Neuroscience, 144, no. 3, 2007, p. 1057.

56.AYALA, A., MUNOZ, M.F., ARGUELLES, S., Oxidative Medicine and Cellular Longevity, Article ID 360438, 2014, http://dx.doi.org/10.1155/ 2014/360438

57.DUMITRU, G., ABIDAR, S., NHIRI, M., HRITCU, L., BOIANGIU, R.S., SANDU, I., TODIRASCU-CIORNEA, E., Rev. Chim. (Bucharest), 69, no. 12,2018, p. 3545.

58.KALUEFF, A. V., GEBHARDT, M., STEWART, A. M., CACHAT, J. M., BRIMMER, M., CHAWLA, J. S., CRADDOCK, C., KYZAR, E. J., ROTH, A., LANDSMAN, S., GAIKWAD, S., ROBINSON, K., BAATRUP, E., TIERNEY, K., SHAMCHUK, A., NORTON, W., MILLER, N., NICOLSON, T., BRAUBACH, O., GILMAN, C. P., PITTMAN, J., ROSEMBERG, D. B., GERLAI, R., ECHEVARRIA, D., LAMB, E., NEUHAUSS, S. C. F., WENG, W., BALLY-CUIF, L., SCHNEIDER, H., Zebrafish Neuroscience Research, C., 10, 2013, p. 70.

59.MARIGOUDAR, S.R., NAZEER AHMED, R., DAVID, M., World Journal of Zoology, 4, no. 1, 2009, p. 19.

60.NEMA, S., BHARGAVA, Y., Neurotoxicology and Teratology, 68, 2018, p. 57.

61.RADHAIAH, V., JAYANTHA, R.K., Environ. Ecol., 6, no. 2, 1988, p. 2. 62.DRUMMOND, R.A., RUSSOM, D.G., DAVID, L.D., Aqua. Toxicol., 9, 1986, p. 415.

63.MURTHY, A.S., Toxicity of pesticides to fish, 2, 1987, p. 55.

64.SANTHAKUMAR, M., BALAJI, M., SARAVANAN, K.R., SOUMADY, D., RAMUDU, K., J. Environ. Biol., 21, no. 1, 2000, p. 65.

$\overline{\text { Manuscript received: } 23.07 .2018}$ 